Int. J. Dev. Biol. 62: 121-126 (2018)

https://doi.org/10.1387/ijdb.170301mn

\title{
A snail tale and the chicken embryo
}

\author{
M. ANGELA NIETO* \\ Instituto de Neurociencias, CSIC-UMH, Sant Joan d'Alacant, Spain
}

\begin{abstract}
Some 25 years ago, a clone was identified that contained the chicken Slug sequences (now called Snail2). How could we anticipate at that time how much the chick embryo would help us to understand the ins and outs of cell migration during development and in disease? Indeed, the chick embryo helped us identify Snail2 as the first transcription factor that could induce the epithelial-mesenchymal transition (EMT), key for the migration of embryonic and cancer cells.
\end{abstract}

KEY WORDS: chicken embryo, neural crest, gastrulation, tumour progression, evo-devo

When Claudio Stern contacted me to participate in this Special Issue of the Int. J. Dev. Biol., a testimony to the role of the chick embryo as a model in developmental biology, my immediate thought was to reflect on how a cloning expedition that started 25 years ago helped us to understand the epithelial to mesenchymal transition (EMT), its impact on morphogenesis and its importance in biomedicine. In 1992, I was fortunate to be a postdoctoral fellow in David Wilkinson's laboratory at the National Institute for Medical Research in London, working in close contact with Robb Krumlauf, Robin Lovell-Badge, Jim Smith, Andrew Lumsden and Claudio Stern, along with other prominent scientists. It was a fantastic time, during which we identified a host of vertebrate genes that were homologues of genes previously identified in Drosophila, and that had been instrumental in teaching us how embryos can develop and establish a body plan. We were embarked on a fishing expedition, to identify genes segmentally-expressed in the hindbrain of the mouse after the discovery of Krox-20 and the segmentally restricted expression of Hoxgenes (Wilkinson et al., 1989a; 1989b; see Parker and Krumlauf, 2017, for a recent review). Having isolated the mouse Snail homologue (Nieto et al., 1992), we thought that we could better understand Snail function if we were to take advantage of the amenability of the chicken embryo for experimental embryology. As such, and along with Mike Sargent, we set out to identify the chick homologue of Snail by screening a cDNA library that we made from more than $600 \mathrm{HH} 10$ stage chicken embryos obtained over just a few days.

Not only did we find Snail but also, another homologue that we initially called "Zip" as it was expressed "at the edges of the neural plate during neural tube closure" (as my notes read on June 30th, 1992: see Fig. 1A). With the help of Claudio Stern, who was optimizing the in situ hybridization protocol for chicken embryos, we enhanced the sensitivity of this technique protocol and soon realized that this gene was expressed in neural crest cells. We named this gene Slug, as it was a paralogue of the chicken Snail gene, and interestingly, we found it in both the premigratory and migratory neural crest populations (Fig. 1B). Years later the HUGO Nomenclature committee suggested naming this gene Snail2 (Snai2: see Barrallo-Gimeno and Nieto, 2005). The pattern of Slug/Snail2 expression was very exciting because at that time there were no markers of the premigratory neural crest and therefore, the appearance of these cells at the top of the neural folds, and their delamination and migration, could only be studied using chick/quail grafts as pioneered by Nicole Le Douarin (Le Douarin, 1973). The migratory crest could be tracked by labelling it with NC-1, an antibody generated against the quail ciliary ganglion by Jean Paul Thiery and that later turned out to recognize the same antigen as $\mathrm{HNK}-1$, that was raised against a human leukemic cell-line (Tucker et al., 1984). Comparing the distribution of Snail2 and HNK-1 in the 2-day-old chicken embryo we confirmed that Snail2 was expressed by both the premigratory and early migratory neural crest (Fig. 1C,D). Interestingly, Snail2 was not expressed in neural crest derivatives, already suggesting that its role could be related to cell movement rather than to cell fate. At this point, at the end of 1992 and having just analysed the expression pattern of this gene, I returned to Spain to set up my laboratory at the Cajal Institute in Madrid.

\section{The epithelial to mesenchymal transition and its connection with tumour progression}

Although important and often very useful, patterns of expression do not always help understand gene function, although it was clear that this transcription factor could play an important role in

Abbreviations used in this paper: EMT, epithelial to mesenchymal transition.

*Address correspondence to: M. Angela Nieto. Instituto de Neurociencias, CSIC-UMH, Avda. Ramon y Cajal s/n, Sant Joan d'Alacant 03550, Spain.
E-mail: anieto@ umh.es (iD) http://orcid.org/0000-0002-3538-840X

Submitted: 6 November, 2017; Accepted: 10 November, 2017.

ISSN: Online 1696-3547, Print 0214-6282 


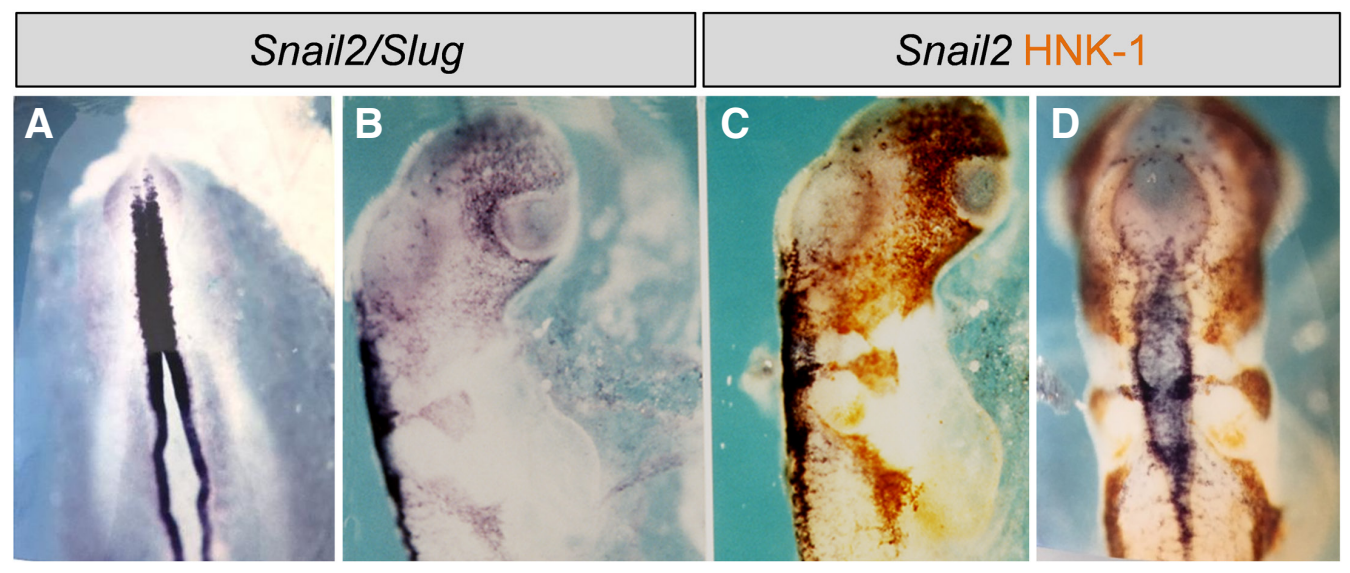

Fig. 1. Expression of Slug/Snail2 in the chick neural crest. (A) Early expression at the edges of the neural plate. (B) Note the expression in both the premigratory and migratory populations. (C, D) The latter is better assessed when compared with that of the migratory crest marker HNK-1. Adapted from Nieto et al. (1994) and Del Barrio and Nieto (2002). the early embryo. Indeed, in addition to the neural crest, it was also expressed strongly in the primitive streak and by the cells that delaminate from it: the early mesoderm and the precursors of the definitive endoderm. I had learned to culture chick embryos with Jonathan Cooke, and when we cultured and incubated them with antisense oligonucleotides to block these genes, we saw the most striking phenotype whereby cells were unable to delaminate and migrate from either the neural tube or the primitive streak (Nieto et al., 1994). Inspired by Ruth Bellairs' concept of mass migration in development, and her comparison between the neural crest and the primitive streak in the chick embryo (Bellairs, 1987), it was clear that this transcription factor was regulating the so-called epithelial-mesenchymal transition (EMT), first studied by Betty Hay in the 60's and also in the chick (Hay, 1968; Hay, 1995). Essentially, cells born far from their final destination implement this programme in order to delaminate, migrate and populate different regions of the embryo.

The fact that we could simultaneously observe the premigratory and the migratory crest populations facilitated the description and analysis of the neural crest under different experimental conditions, something that was immediately appreciated by Nicole Le Douarin who was extremely supportive of our work from the very

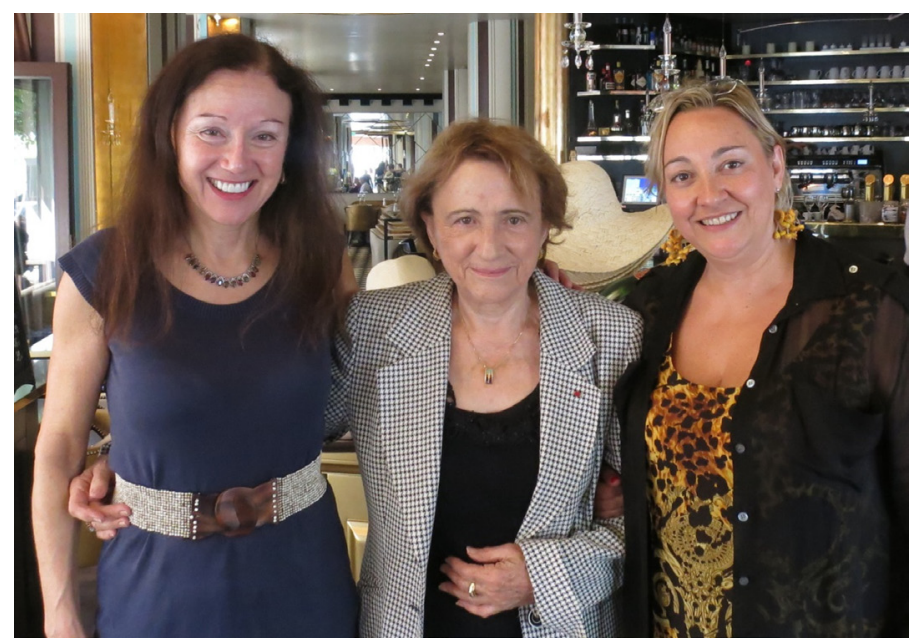

Fig. 2. Meeting during the FEBS-EMBO 2014 Conference in Paris. The conference celebrated the 50th anniversaries of FEBS and EMBO and the 100th anniversary of the French Society for Biochemistry and Molecular Biology. The author with Marianne Bronner (left) and Nicole Le Douarin (middle). beginning (Le Douarin et al., 1994). We continued our collaboration with Dave Wilkinson and Marianne Bronner using Snail2 alone as a marker (Nieto et al., 1995). Experiments were carried out jointly in Spain, the UK and US, proving to be a truly fantastic example of collaborative work and publishing the results before I had even met Marianne in person. The chick embryo has continued to be a key model in the analysis of developmental processes (Stern, 2005; Gerety et al., 2013) and in particular, of the neural crest (Le Douarin and Dieterlen-Lièvre, 2013; Martik and Bronner, 2017, and references therein), for which Nicole and Marianne have played instrumental roles (see Fig. 2).

When we first described the phenotype of Slug/Snail2 defective chick embryos, we proposed that "pathological activation of Slug or of functionally related genes could contribute to the onset of the invasive or metastatic phenotype during the progression of cancers of epithelial origin, because the ability to break through an epithelial basement structure is reminiscent of the mechanism by which mesoderm and the neural crest originate" (Nieto et al., 1994). Although it took us several years, along with Amparo Cano we finally showed that Snail was indeed activated in dedifferentiated carcinomas, and at the same time as Antonio Garcia de Herreros in Barcelona, that Snail acted as a repressor of E-Cadherin transcription (Cano et al., 2000; Batlle et al., 2000; Blanco etal., 2002), the loss of which was known to be fundamental for the transition from adenoma to invasive carcinoma (Behrens et al., 1989; Perl et al., 1998). Snail proteins could induce a cellular transition compatible with the EMT (Fig. 3) and reminiscent of that observed in a new fibroblastic cell type originated from tumour-derived mammary epithelial cells (Dulbecco et al., 1981) and when epithelial carcinoma bladder cells were incubated with epidermal growth factor (EGF: Boyer et al., 1988; 1992). Other transcription factors from different gene families have been later shown to induce EMT and they may be reactivated at the invasive front of carcinomas of different aetiologies (see Ye and Weinberg, 2015; Nieto et al., 2016, for recent comprehensive reviews).

The dynamics of the EMT is complex and it is a transient process; tumour cells reacquire epithelial traits to engage in metastatic colonization, as do migratory embryonic cells upon reaching their destination. Moreover, it has proven difficult to generate appropriate animal models that can follow the whole process. Accordingly, it has been extremely difficult to study how EMT influences the progression of carcinomas. For instance, it has not been possible to reliably observe tumour cells all the way from the primary tumour to the metastatic site, fuelling discussion 


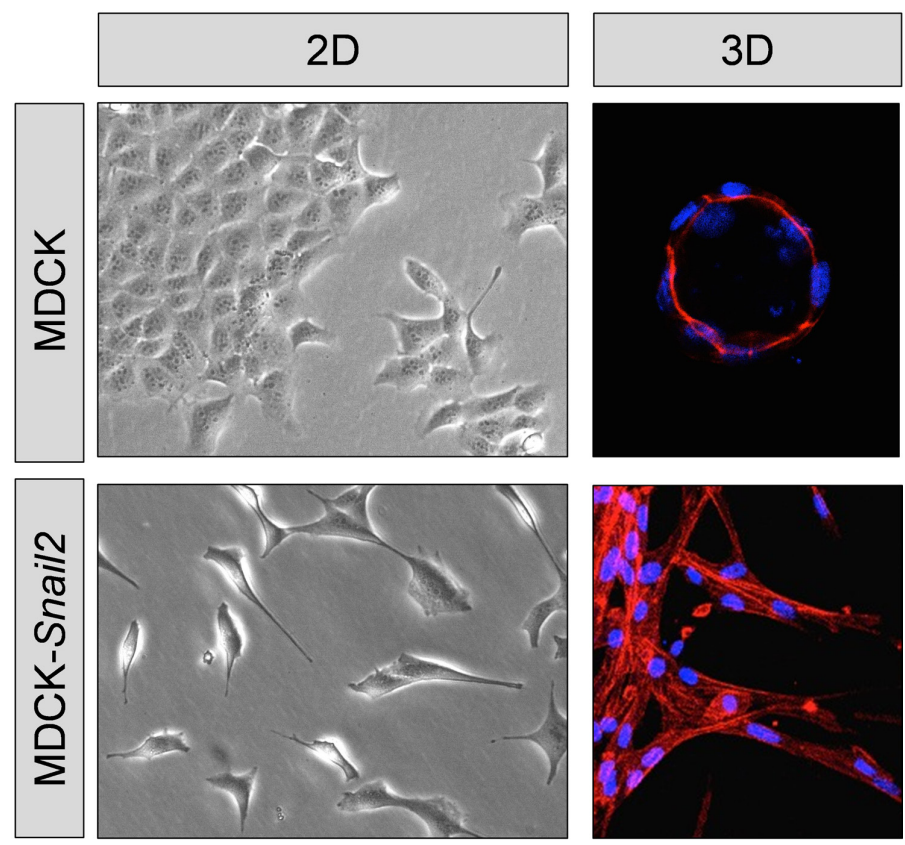

Fig. 3. Epithelial cells (MDCK cell line) undergo epithelial to mesenchymal transition (EMT) upon activation of Snail2/Slug. Images show cells grown in 2D or embedded in Matrigel (3D). In Matrigel, MDCK cells form epithelial ducts, whereas Snail2-expressing MDCK cells form mesenchymal networks.

and encouraging those working in the field to design models better optimized to understand these processes. Indeed, the EMT and its significance in the initial steps of the metastatic cascade remain the subject of some debate (Brabletz et al., 2017). Ironically, as early as 1890 Cajal already noticed this cellular transition and its implication in the invasive potential of breast carcinoma (Ramón y Cajal, 1890a; Text and Fig. 48 in the first Edition). Interestingly, and in the context of this special issue dedicated to the chick embryo, Cajal's neuronal theory, that neurons were individual entities, was formulated on the basis of his studies of the axons sprouting from spinal commissural neurons in the chick embryo (Ramón y Cajal, 1890b).

In summary, the importance of the EMT in tumour progression and in other diseases would have surely remained elusive without the contribution of the instrumental studies carried out on chicken embryos. These studies defined the cellular events associated with the EMT and many of the fundamental elements involved. Going back to the Snail genes, unexpected findings often made them somewhat difficult to work with, issues that over time have developed into interesting evo-devo and tissue-specific stories, the nature of which I will outline below.

\section{Were the test tubes switched or is evolution playing tricks on us?}

After finding that in the chick embryo, Snail2/Slug was required by cells in the neural tube and primitive streak to delaminate, and having connected this event with cancer, it was clear that we needed to study this process in mammals. We set out to better characterize Snail and Slug in the chick and mouse, and we were frankly dismayed when we studied their expression patterns, as we seemed to have somehow swapped the test tubes in the lab. Indeed, the pattern of Slug expression in the mouse was not only different from what we had seen in the chicken but significantly, it was very similar to that of Snail in the chick (Fig. 4). Eventually, it dawned on us that the main expression domains of Snail and Slug were interchanged between the chick and mouse (Sefton et al., 1998). As such, we predicted that the Slug mutant mice would probably not have a gastrulation or strong neural crest phenotype, as this gene was rather expressed in subpopulations of migratory mesoderm and neural crest cells. This was confirmed by Tom Gridley (Jiang et al., 1998), who later also showed that it was in fact the Snail rather than the Slug gene that was required for EMT in the gastrulating mouse embryo (Carver et al., 2001). By then, we had already drawn the connection between E-cadherin and cancer cells, also confirming that Snail was the prominent family member for EMT in mammalian cells (Cano et al., 2000).

After observing how the expression domains of chick and mouse Snail and Slug had been swapped around, we started another fishing expedition to isolate Snail genes in representatives of all the vertebrate groups. We found an unprecedented degree of reshuffling in the expression domains of these genes, some of which could be explained by neofunctionalisation or subfunctionalisation, whereas others did not fit the models of tissue-specific
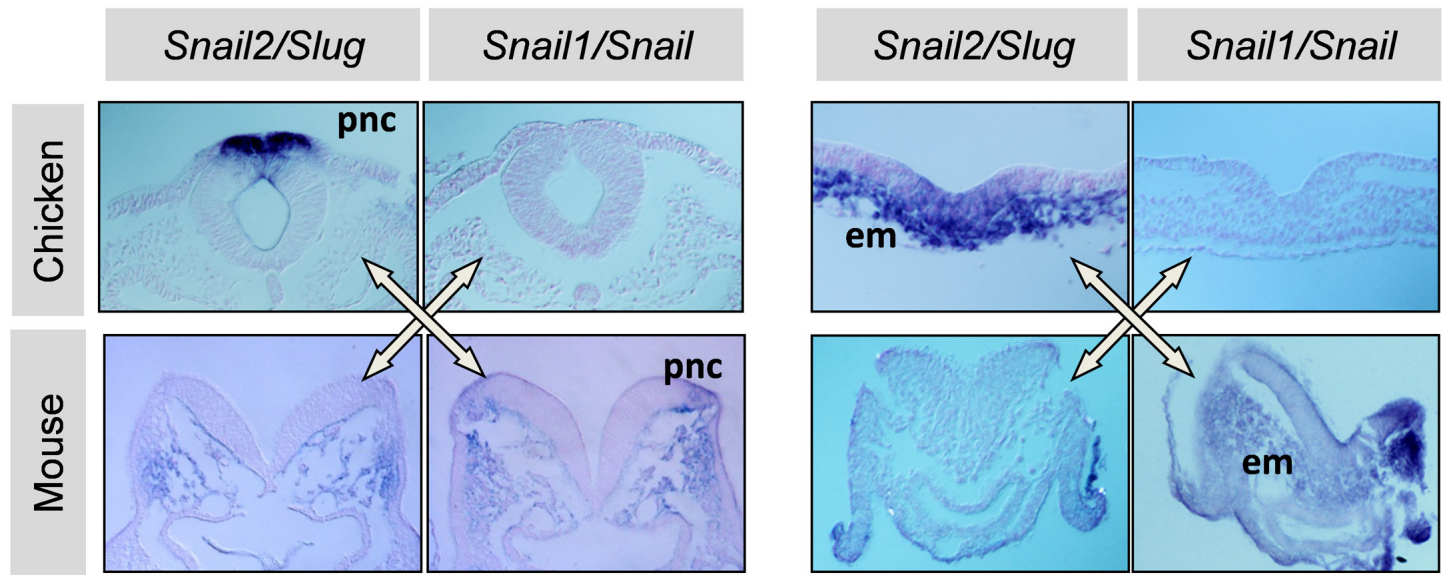

Fig. 4. The expression patterns of Snail1 and Snail2 are interchanged in the premigratory neural crest and the early mesoderm in the chick and the mouse. Adapted from Sefton et al. (1998) and Nieto (2002). 
enhancer rearrangement during evolution (Locascio et al., 2002). In fact, more recently we also observed that the role played by $\mathrm{E}$-cadherin at gastrulation stages in the mouse is likely played by P-cadherin in the chick (Acloque et al., 2017).

Another recent example of this phenomenon is the case of $\mathrm{L} / \mathrm{R}$ asymmetry and organ positioning. Perhaps it should be of no surprise that the chick embryo has been at the centre stage of research into organ positioning for many years. The seminal experiments describing transient activation of the Activin receptorShh-Nodal-Pitx2 pathway on the left side of the embryo were performed in the chick (Levin et al., 1995; Logan et al., 1998; Piedra et al., 1998; Ryan et al., 1998; Yoshioka et al., 1998). Moreover, Snail was shown to be expressed more strongly on the right side of the chick embryo, where it repressed Pitx2 expression (Patel et al., 1999). Therefore, the model was that organ positioning, and heart situs in particular, was driven by conferring left-handed information to the left side of the embryo and excluding it from the right. However, although the expression of Pitx2 in the chick and mouse embryos is very similar and restricted to the left lateral plate mesoderm, Pitx2 mouse mutants do not display heart looping defects but rather, they develop cardiac right isomerism -the absence of a left-hand side and the presence of a mirror image duplication of right-hand morphological features (Lin et al., 1999; Campione et al., 2001). Indeed, Pitx2 is crucial to impart left-handed information (Raya and Izpisua-Belmonte, 2006) and for axis formation (Torlopp et al., 2014), yet not for heart looping. Importantly, heart looping seems to be independent of Nodal in the zebrafish (Noël et al., 2013). In addition, the development and position of the proepicardium, a transient right-specific structure in frogs and avians, is not affected by aberrant bilateral Pitx2 expression (Schlueter and Brand, 2009). Together, these data suggest that as well as the left-handed pathway, an additional instructive pathway might exist that conveys information from the right hand side of the embryo. As such, Prrx1, another transcription factor containing an OAR transactivation domain like Pitx2, is activated by BMP more prominently on the right flank and its downregulation induces mesocardia in the zebrafish (Ocaña et al., 2017: Fig. 5). Interestingly, like Snail, Prrx induces EMT in embryos and cancer cells (Ocaña et al., 2012), suggesting that there might be some common features between the EMT and the mechanisms that drive heart looping. In fact, L/R asymmetric Prrx1 expression and accordingly, L/R asymmetric EMT, drives asymmetric cell movements and forces that produce a leftward displacement of the posterior pole of the heart and hence, normal looping (Ocaña et al., 2017). Once again, it seemed strange that Prrx1 mutant mice did not display heart-positioning defects (Bergwerff et al., 2000). However, the expression of Prrx1 in the region relevant for heart looping in the fish had been substituted by that of Snail1 in the mouse. This explains the lack of a heart laterality phenotype in the Prrx1 mutants and the heart looping defects described in Snail1 mutant embryos (Murray et al., 2006). Here is when the chick embryo helped us again. Both Prrx1 and Snail 1 contribute to heart looping in the chick, as they are expressed in complementary patterns in the relevant territories, an intermediate situation to that found in the fish and mouse. Functional analysis in the three model systems confirmed that an asymmetric L/R EMT, more prominent on the right, drives heart looping in vertebrates, significantly through a conserved cellular morphogenetic process driven by different EMT inducers over the course of vertebrate evolution (Ocaña et al., 2017). This has important implications, particularly since heart looping is crucial for the concordance between the heart and the vasculature. Defects in L/R asymmetry arise in 1/10,000 humans, and the associated morbidity and mortality are usually associated with congenital heart defects (CHDs: Lin et al., 2014; Ramsdell et al., 2005).

In summary, in some of the experiments described here, evolution seems to have been playing with us. In one case, different gene family members, generated following whole genome duplications at the base of the vertebrate lineage (Mclysaght et al., 2002), play the same role in different species. For heart positioning, the cellular process is conserved but the transcription factor used belongs to a different gene family. Importantly, all of the above, has taught us that if we really want to understand what particular genes do and how they are integrated into a developmental or pathological process, we need to study different models before we can extrapolate data obtained from a single species or vertebrate group to others. This is particularly important when translating studies performed in animal models into medical research. We now try to address our questions simultaneously in the chicken, mouse and fish, even though this implies a more significant effort. As a result, in all our projects we can guarantee that the chick embryo will always be there to help us tell the complete tale.
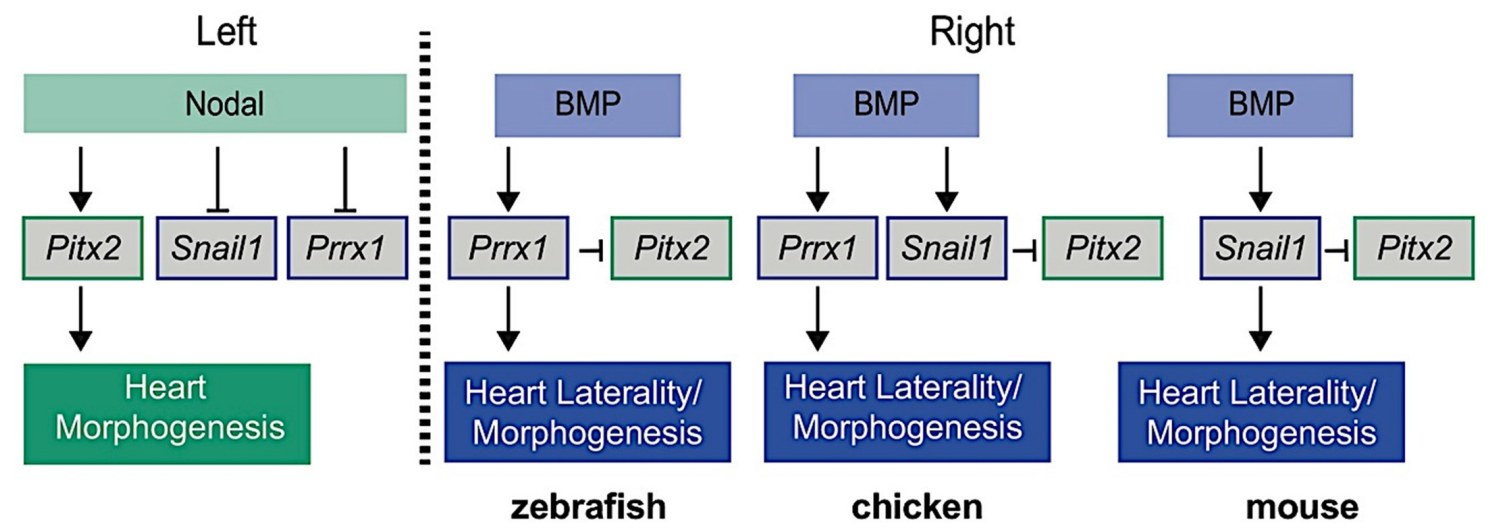

Fig. 5. A differential left-right EMT regulates heart laterality in vertebrates. In addition to the well-known left-specific Nodal-Pitx2 axis, a BMPinduced EMT program, more prominent on the right side, triggers the leftward displacement of the posterior pole of the heart. The EMT-TFs used vary in different vertebrate groups. Adapted from Ocaña et al., (2017). 


\section{Acknowledgements}

I would like to acknowledge here all the prominent developmental biologists that showed me the beauty of the developing embryo in the early 90's and my collaborators over the years, both in and out of the lab. The work in my laboratory is currently supported by the Spanish Ministry of Economy and Competitiveness (BFU2008-01042) and the European Research Council (ERC AdG 322694), and by the Spanish Research Agency (AEI), through the "Severo Ochoa" Programme for Centres of Excellence in R\&D (SEV-2103-0317) to the Instituto de Neurociencias.

\section{References}

ACLOQUE H, OCAÑA OH, ABAD D, STERN CD, NIETO MA (2017). Snail2 and Zeb2 repress P-cadherin to define embryonic territories in the chick embryo. Development 144: 649-656.

BARRALLO-GIMENO A, NIETO MA (2005). The Snail genes as inducers of cell movement and survival: implications in development and cancer. Development 32: 3151-3161.

BATLLE E, SANCHO E, FRANCÍ C, DOMÍNGUEZ D, MONFAR M, BAULIDA J, GARCIA DE HERREROS A (2000). The transcription factor snail is a repressor of E-cadherin gene expression in epithelial tumour cells. Nat Cell Biol. 2: 84-89.

BELLAIRS, R (1987). The primitive streak and the neural crest: comparable regions of cell migration? In Developmental and Evolutionary Aspects of the Neural crest. P. Maderson Ed. Jhon Wiley \& Sons, new York, 1987. pp123-145.

BENNETT DC, PEACHEY LA, DURBIN H, RUDLAND PS (1978). A possible mammary stem cell line. Cell 15: 283-298.

BERGWERFF M, GITTENBERGER-DE GROOT AC, WISSE LJ, DERUITER MC, WESSELS A, MARTIN JF, OLSON EN, KERN MJ (2000). Loss of function of the Prx1 and Prx2 homeobox genes alters architecture of the great elastic arteries and ductus arteriosus. Virchows Arch. 436: 12-19.

BEHRENS J, MAREEL MM, VAN ROY FM, BIRCHMEIER W (1989). Dissecting tumor cell invasion: epithelial cells acquire invasive properties after the loss of uvomorulin-mediated cell-cell adhesion. J Cell Biol. 108: 2435-2447.

BLANCO MJ, MORENO-BUENO G, SARRIO D, LOCASCIO A, CANO A, PALACIOS J, NIETO MA (2002). Correlation of Snail expression with histological grade and lymph node status in breast carcinomas. Oncogene 21: 3241-3246.

BOYER B, DUFOUR S, THIERY JP. (1992). E-cadherin expression during the acidic FGF-induced dispersion of a rat bladder carcinoma cell line. Exp Cell Res. 201: 347-357.

BOYER B, TUCKER GC, VALLÉS AM, GAVRILOVIC J, THIERY JP. (1989). Reversible transition towards a fibroblastic phenotype in a rat carcinoma cell line. Int $J$ Cancer Suppl. 4: 69-75.

BRABLETZ T, KALLURI R, NIETO MA, WEINBERG RA (2018). View Point on EMT. Nat Rev Cancer. (In press) doi: 10.1038/nrc.2017.118

CAMPIONE M, ROS MA, ICARDO JM, PIEDRA E, CHRISTOFFELS VM, SCHWEICKERT A, BLUM M, FRANCO D, MOORMAN AF (2001). Pitx2 expression defines a left cardiac lineage of cells: evidence for atrial and ventricular molecular isomerism in the iv/iv mice. Dev. Biol. 231: 252-264.

CANO A, PÉREZ-MORENO MA, RODRIGO I, LOCASCIO A, BLANCO MJ, DEL BARRIO MG, PORTILLO F, NIETO MA (2000). The transcription factor snail controls epithelial-mesenchymal transitions by repressing E-cadherin expression. Nat Cell Biol. 2: 76-83.

CARVER EA, JIANG R, LAN Y, ORAM KF, GRIDLEY T (2001). The mouse snail gene encodes a key regulator of the epithelial-mesenchymal transition. Mol Cell Biol. 21: 8184-8188.

DEL BARRIO MG, NIETO MA (2002). Overexpression of Snail family members highlights their ability to promote chick neural crest formation. Development 129: 1583-1593.

DULBECCO R, HENAHAN M, BOWMAN M, OKADA S, BATTIFORA H, UNGER M (1981). Generation of fibroblast-like cells from cloned epithelial mammary cells in vitro: a possible new cell type. Proc Natl Acad Sci USA. 78: 2345-2349.

GERETY SS, BREAU MA, SASAI N, XU Q, BRISCOE J, WILKINSON DG (2013). An inducible transgene expression system for zebrafish and chick. Development 140: 2235-2243.

HAY ED (1968). Organization and fine structure of the epithelium and mesenchyme in the developing chick embryo. In Fleischmajer R, RE Billingham (Eds). EpithelialMesenchymal Interactions. Blatimore, Williams and Wilkins pp31-35.

HAY ED (1995). An overview of epithelio-mesenchymal transformation. Acta Anat (Basel). 154: 8-20.

JIANG R, LAN Y, NORTON CR, SUNDBERG JP, GRIDLEY T (1998). The Slug gene is not essential for mesoderm or neural crest development in mice. Dev Biol. 198: 277-285

LE DOUARIN N (1973) A biological cell labeling technique and its use in experimental embryology. Dev. Biol. 30: 217-222.

LE DOUARIN NM, DIETERLEN-LIĖVRE F (2013). How studies on the avian embryo have opened new avenues in the understanding of development: a view about the neural and hematopoietic systems. Dev Growth Differ. 55: 1-14.

LE DOUARIN NM, DUPIN E, ZILLER C (1994). Genetic and epigenetic control in neural crest development. Curr Opin Genet Dev. 4: 685-695.

LEVIN M, JOHNSON RL, STERN CD, KUEHN M, TABIN C (1995). A molecular pathway determining left-right asymmetry in chick embryogenesis. Cell 82: 803-814.

LIN AE, KRIKOV S, RIEHLE-COLARUSSO T, FRÍAS JL, BELMONT J, ANDERKAM, GEVA T, GETZ KD, BOTTO LD; National Birth Defects Prevention Study (2014). Laterality defects in the national birth defects prevention study (1998-2007): birth prevalence and descriptive epidemiology. Am. J. Med. Genet. A. 164A:2581-2591.

LINCR, KIOUSSIC, O'CONNELLS, BRIATAP, SZETO D, LIU F, IZPISUA-BELMONTE JC, ROSENFELT MG (1999). Pitx2 regulates lung asymmetry, cardiac positioning and pituitary and tooth morphogenesis. Nature 401: 279-282.

LOCASCIO A, MANZANARES M, BLANCO MJ, NIETO MA (2002). Modularity and reshuffling of Snail and Slug expression during vertebrate evolution. Proc. Natl. Acad. Sci. USA. 99: 16841-16846.

LOGAN M, PAGÁN-WESTPHAL SM, SMITH DM, PAGANESSI L, TABIN CJ (1998). The transcription factor Pitx2 mediates situs-specific morphogenesis in response to left-right asymmetric signals. Cell 94: 307-317.

MARTIK ML, BRONNER ME (2017). Regulatory Logic Underlying Diversification of the Neural Crest. Trends Genet. 33:715-727 (doi: 10.1016/j.tig.2017.07.015)

MCLYSAGHT A, HOKAMP K, WOLFE KH (2002). Extensive genomic duplication during early chordate evolution. Nat Genet. 31: 200-204.

MURRAY SA, GRIDLEY, T (2006). Snail family genes are required for left-right asymmetry determination, but not neural crest formation, in mice. Proc. Natl. Acad. Sci. USA 103: 10300-10304.

NIETO MA (2000). The snail superfamily of zinc-finger transcription factors. Nat Rev Mol Cell Biol. 3: 155-166.

NIETO MA (2013). Epithelial plasticity: a common theme in embryonic and cancer cells. Science. 342: 1234850.

NIETO MA, BENNET MF, SARGENT MG, WILKINSON DG (1992). Cloning and developmental expression of Sna, a murine homologue of the Drosophila snail gene. Development 116: 227-237.

NIETO MA, HUANG R Y-J, JACKSON RA, THIERY JP (2016). EMT: 2016. Cell 166: 21-45.

NIETO, MA, SARGENT M, WILKINSONDG, COOKE J (1994). Control of cell behavior during vertebrate development by Slug, a zinc-finger gene. Science 264: 836-840.

NIETO MA, SECHRIST J, WILKINSON DG, BRONNER-FRASER M (1995) Relationship between spatially restricted Krox-20 gene expression in branchial neural crest and segmentation in the chick embryo hindbrain. EMBO J. 14: 1697-1710.

NOËL ES, VERHOEVEN M, LAGENDIJK AK, TESSADORI F, SMITH K, CHOORAPOIKAYIL S, DEN HERTOG J, BAKKERS J (2013). A Nodal-independent and tissue-intrinsic mechanism controls heart-looping chirality. Nat. Commun. 4:2754

OCAÑA OH, CÓRCOLES R, FABRA A, MORENO-BUENO G, ACLOQUE H, VEGA S, BARRALLO-GIMENO A, CANO A, NIETO MA (2012). Metastatic colonization requires the repression of the epithelial-mesenchymal transition inducer Prrx1. Cancer Cell 22: 709-724.

OCAÑAOH, COSKUNH, MINGUILLÓNC, MURAWALAP, TANAKAEM, GALCERÁN J, MUÑOZ-CHAPULI R, NIETO MA (2017). A right-handed signalling pathway drives heart looping in vertebrates. Nature 549:86-90. (doi: 10.1038/nature23454).

PATELK, ISAACA, COOKEJ (1999). Nodal signaling and the roles of the transcription factors SnR and Pitx2 in vertebrate left-right asymmetry. Curr. Biol. 9: 609-612.

PARKER HJ, KRUMLAUF R (2017). Segmental arithmetic: summing up the Hox gene regulatory network for hindbrain development in chordates. WIREs Dev. Biol. 6 : e286. doi:10.1002/wdev.286 


\section{M.A. Nieto}

PERLAK, WILGENBUS P, DAHLU, SEMB H, CHRISTOFORI G (1998). A causal role for E-cadherin in the transition from adenoma to carcinoma. Nature 392: 190-193.

PIEDRA ME, ICARDO JM, ALBAJAR M, RODRIGUEZ-REY JC, ROS MA (1998). Pitx2 participates in the late phase of the pathway controlling left-right asymmetry. Cell 94: 319-324.

RAMON Y CAJAL S (1890a) In "Manual de Anatomía Patológica General" Barcelona Imprenta de la Casa Provincial de la Caridad. First Edition.

RAMÓNYCAJALS(1890b). Aquelle époque apparaissent les expansions des cellules nerveuses de la moelle épinière du poulet. Anatomischer Anzeiger 5: 609-613.

RAMSDELLAF (2005). Left-right asymmetry and congenital cardiac defects: getting to the heart of the matter in vertebrate left-right axis determination. Dev. Biol. 288: 1-20.

RAYAA, IZPISÚA BELMONTE JC (2006). Left-right asymmetry in the vertebrate embryo: from early information to higher-level integration. Nat Rev Genet. 7:283-293.

RYANAK, BLUMBERG B, RODRIGUEZ-ESTEBAN C, YONEI-TAMURAS, TAMURA K, TSUKUI T, DE LA PEÑAJ, SABBAGH W, GREENWALD J, CHOE S, NORRIS DP, ROBERTSON EJ, EVANS RM, ROSENFELD MG, IZPISÚA BELMONTE JC (1998). Pitx2 determines left-right asymmetry of internal organs in vertebrates. Nature 394: 545-551.

SCHLUETER J, BRAND T. (2009). A right-sided pathway involving FGF8/Snai1 controls asymmetric development of the proepicardium in the chick embryo. Proc. Natl. Acad. Sci. USA 106: 7485-7490.

SEFTON M, SÁNCHEZ S, NIETO MA (1998). Conserved and divergent roles for members of the Snail family of transcription factors in the chick and mouse embryo. Development 125: 3111-3121.

STERN CD (2005). The chick; a great model system becomes even greater. Dev Cell 8: 9-17.

TORLOPP A, KHAN MA, OLIVEIRA NM, LEKK I, SOTO-JIMÉNEZ LM, SOSINSKY A, STERN CD (2014). The transcription factor Pitx2 positions the embryonic axis and regulates twinning. Elife 3:e03743. doi: 10.7554/eLife.03743.

TUCKER GC, AOYAMA H, LIPINSKI M, TURSZ T, THIERY JP (1984). Identica reactivity of monoclonal antibodies HNK-1 and NC-1: conservation in vertebrates on cells derived from the neural primordium and on some leukocytes. Cell Differ. 14: $223-230$

WILKINSON DG, BHATTS, CHAVRIER P, BRAVO R, CHARNAY P (1989). Segmentspecific expression of a zinc-finger gene in the developing nervous system of the mouse. Nature 337: 461-464.

WILKINSON DG, BHATT S, COOK M, BONCINELLI E, KRUMLAUF R (1989). Segmental expression of Hox-2 homoeobox-containing genes in the developing mouse hindbrain. Nature 341: 405-409.

YEX, WEINBERG RA (2015). Epithelial-Mesenchymal Plasticity: A Central Regulator of Cancer Progression. Trends Cell Biol. 25: 675-686.

YOSHIOKA H, MENO C, KOSHIBA K, SUGIHARA M, ITOH H, ISHIMARU Y, INOUE T, OHUCHI H, SEMINA EV, MURRAY JC, HAMADA H, NOJI S (1998). Pitx2, a bicoid-type homeobox gene, is involved in a lefty-signaling pathway in determination of left-right asymmetry. Cell 94: 299-305. 


\section{Further Related Reading, published previously in the Int. J. Dev. Biol.}

Snail is an immediate early target gene of parathyroid hormone related peptide signaling in parietal endoderm formation J M Veltmaat, C C Orelio, D Ward-Van Oostwaard, MA Van Rooijen, C LMummery and LH Defize Int. J. Dev. Biol. (2000) 44: 297-307

http://www.intjdevbiol.com/web/paper/10853826

Expression of the transcription factor slug correlates with growth of the limb bud and is regulated by FGF-4 and retinoic acid

P G Buxton, K Kostakopoulou, P Brickell, P Thorogood and P Ferretti

Int. J. Dev. Biol. (1997) 41: 559-568

http://www.intjdevbiol.com/web/paper/9303343

Epithelial-Mesenchymal Transitions in development and disease: old views and new perspectives

M. Angela Nieto

Int. J. Dev. Biol. (2009) 53: 1541-1547

https://doi.org/10.1387/ijdb.072410mn

Origin and evolution of endoderm and mesoderm

Ulrich Technau and Corinna B Scholz

Int. J. Dev. Biol. (2003) 47: 531-539

http://www.intjdevbiol.com/web/paper/14756329

5 yr ISI Impact Factor $(2016)=2.421$
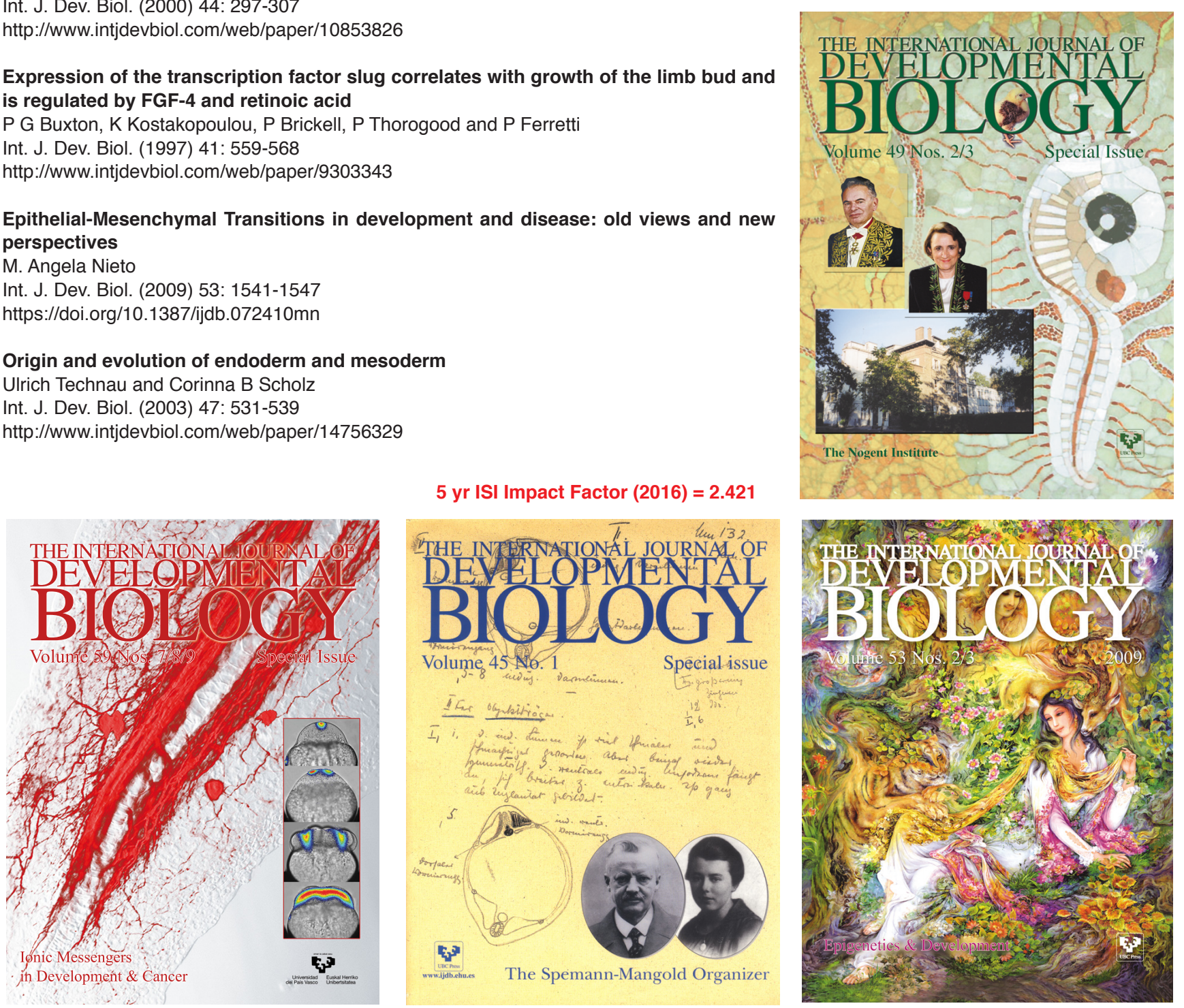